\title{
ESL in Australia - A chequered history
}

\section{RHONDA OLIVER $^{(a)}$, JUDITH ROCHECOUSTE ${ }^{(b)}$ AND BICH NGUYEN (a) \\ ${ }^{(a)}$ Curtin University, ${ }^{(b)}$ Lingwa Consultancy}

Abstract: A historical perspective of English as a second or additional language (ESL/EAL) in Australia reveals the field as in a constant state of flux, in spite of Australia's status as a nation of immigrants. This paper provides a contemporary review of the various phases of English language teaching in Australia for both adults and school-aged learners. It does so in the context of earlier pro-British monolingual attitudes, external global forces, ongoing changes in education policy, more recent national assessment regimes and the various global and local developments in the teaching of second languages.

Historically the impetus for teaching English as a Second Language came with large-scale post-World War II arrivals from Europe. Language support for child migrants was only introduced some time later and has continued, although decreasing in availability in recent years. From the 1970s, more focussed programs were instigated with the arrival of refugees from war-torn countries. In this paper we describe the constant changes experienced by the providers and the recipients of English language instruction in Australia.

Theoretically, the development of ESL instruction in Australia began with an essentially post-colonial perspective whereby the process of assimilation focussed on normalising the difference and/or deficit of non-English speakers and attaining the language skills of normative white middle-class native speakers (Pavlenko, 2003). Despite various investments in multiculturalism, the non-native English speaker in Australia remains the 'other', subject to sometimes intermittent and ad hoc funded assistance.

Keywords: ESL history; EAL/D; child migrant education; AMEP

\section{Introduction}

From the end of World War II in 1945 to the present day, Australia's population has risen from 7 million to 23 million and much of this increase is largely attributable to migration. Migration in this 
context, from the post WWII decade until today, has remained the focus of considerable social concern and government policy enforcing a "normative Australian-ness" (Faine, 2008).

The influx of immigrants has included large numbers from non-English speaking backgrounds not only seeking a better life, but also those seeking refuge from numerous socio-political, economic and historical forces. In spite of this, the widespread introduction of ESL teaching was considerably delayed due to postwar monolingual, pro-British sentiments. The lack of English, Australia's de facto official language, only became regarded as a "major barrier to effective participation in Australian society" (Australian Institute of Multicultural Affairs, 1980, p. 13) in the 1970s. At this time ESL teaching became more widely available to help migrants overcome communication and integrative obstacles. However, continual modifications to policy, provision and pedagogy have resulted in a somewhat chequered history for teaching ESL in Australia. In this paper we draw on existing literature providing a historical account and examination of the shifting status of Australian ESL policies and practices from post-World War II to the current period.

This history lends itself to interpretation through Postcolonial Theory. In particular we see the maintenance of 'difference' and 'otherness' which was held in stark contrast to the social and cultural norms of the Anglo-Celtic native speaker. Initially there was determined suppression of 'otherness/difference' through the continued support for assimilation, "where notions of cultural dominance and marginality are quite clearly defined" (Sakellaridou 1995, p. 142). As stated by Faine (2008), the "....binary between an imagined homogenous Australia and the 'migrant' as essentially other, has worked against the inclusion of the learner into the dominant groups ..." (p. 4). Moreover, through the discourses of 'otherness', migrants were seen to be inferior and limited. This is reflected in those terms often used to describe them (e.g., "Orientalism", Said, 1995) whereby Western thought was considered to represent the truth and that of any other cultures was deemed inferior. In turn, these "normative representations" (Giroux, 1994) were "regulative and productive of government policies, including ESL" (Faine, 2008, p. 75).

Eventually, this post-colonial paradigm was replaced by Multiculturalism - or what Said (1989:213) calls the "relentless celebration" of "difference" and "otherness". However, as Gunew (n.d.) points out, Post-colonialism and Multiculturalism do 
converge because of their shared focus on 'difference'. Subsequent policy and practices, continuing to the present day, show consistent waves fluctuating between 'fairness' and 'otherness' with both positive and negative consequences. The following sections describe how these fluctuations have shaped the history of ESL in Australia.

\section{Early post-Word War II period - assimilation}

Between World War II (WWII) and 1977, more than two million migrants arrived in Australia. Initially these were from European countries such as Great Britain, Netherlands, Norway, France, Belgium, Poland and Denmark. Non-Europeans were only admitted for business reasons (Australian Government, n.d.; Ozolins, 1993). However, the vulnerability felt by Australians after WWII (which gave rise to the expression "Populate or Perish" ${ }^{1}$ ) soon brought about the extension of assisted migration schemes throughout Europe and beyond.

During this time a post-colonial 'monolingual English only' perception dominated policy and pedagogy (Hannan, 2009; Rhydwen, 1994). Even as late as 1969, sentiments such as "We must have a single culture. We do not want pluralism." (Federal Immigration Minister, Billy Sneddon, 1969, cited in Ingram, 2003, p. 6) reflected a somewhat distorted view of mainstream Australian society by contributing to a "unifying picture of ourselves" (Faine, 2008, p. 75).

The progress of migrant English language education soon established itself on two trajectories - adult learning and school learning, each with evolving pedagogies. Initially the Adult Migrant English Program (AMEP) was set up "as ship-board English tuition for post-war displaced and refugee populations" (Lo Bianco, 2008, p. 347). AMEP was established by the Federal Government in 1947 to encourage adult (but not child, Ozolins \& Clyne, 2001) settlement and social inclusion (Burns \& de Silva Joyce, 2007; Lo Bianco, 2002; Lo Bianco, 2008; Lowes, 2004; Moore, 2007; Piller \& Takahashi, 2011). Thus the aim of AMEP was "pragmatic and assimilation-oriented" (Ozolins \& Clyne, 2001, p. 378) and sought to normalize any differences between Australian citizens and newly arrived migrants thus conforming to a post-colonial mindset. Yet

\footnotetext{
(1) "Populate or Perish" was the slogan used by the Chifley post-war Labor government (1946-1949) to overcome resistance to a policy of mass immigration.
} 
despite this less than auspicious start and since its establishment, the AMEP program over the years has attracted major government investment and received support from all political streams in Australia (Lo Bianco, 2008).

For migrant children, however, cultural diversity and ethnic identity were less well recognised in this post-war period. Children were treated "in exactly the same way, as if they were all little AngloSaxons" (Australian Institute of Multicultural Affairs, 1980, p. 21). As Harris (1980) asserts, "Once [the children] are enrolled in school, they are, from our point of view, Australian children" (p. 26) and as a consequence little was done to assist their transition into mainstream schooling and society.

In terms of teaching pedagogy, in this period the dominant methodology was "traditional language teaching" (Ingram, 1989, p. 54) and despite attitudinal changes towards migration and multiculturalism, this pedagogy continued to dominate for some time. It was underpinned by two theoretical beliefs. Firstly, language was seen as "a set of discrete building blocks comprised of lexis and structures" (Feez, 1999a, p. 6) and, therefore, language learning simply involved the accumulation of these (Feez, 1998, p. 4). Secondly, language learning was strongly grounded in behaviourism as it was deemed "a process of developing correct language habits which are learned through stimulus" (Feez, 1999a, p. 6). For instance, the Australian situational method was structural in its organisation and presentation (Burns \& Joyce, 2007, p. 8; Ingram, 2003, p. 2; Piller \& Takahashi, 2011, p. 594) being comprised of three phases of instruction: social phases, grammatical structures and Australian culture (Piller \& Takahashi, 2011, p. 594). It was presented through segments of language and short sentences through drawings, realia and hand signs (Ingram, 2003, p. 6) with an emphasis on teaching in the target language, namely English (Martin, 1998). Structures and vocabulary were graded according to the perceived level of difficulty (although there was no empirical evidence for these developmental levels); taught in connection with the situations in which adult learners might find themselves; and practised in drills, repetition and dialogue (Feez, 1998, p. 4; Feez, 1999a, p. 6). According to the AMEP workbook used in that period, Situational English part 3, language was presented "situationally in sentence patterns which show their function and meaning and which are arranged in carefully graded teaching order" (Australian Government, 1975, p. v). 


\section{Mid-1960s to mid-1980s}

During this period ESL provision was heavily influenced by largescale non-European immigration programs which were initiated in response to a perceived lack of security, a fear of population decline, a need to establish a nationality that distinguished Australia from Britain, and a redefinition of Australia in relation to the South-East Asian region (Burns \& de Silva Joyce, 2007; Collins, 1988; Ingram, 2003; Ozolins, 1993; Ozolins \& Clyne, 2001). Even with the removal of the "White Australia" policy, all migrants had to follow the same migration procedures, such as the ability to integrate and to have or gain appropriate qualifications (Australian Government, 2013a). However, during this time, Australia also responded to humanitarian calls for refugee resettlement resulting from the 1968 earthquake in Sicily, the Soviet invasion of Czechoslovakia in 1968, the overthrow of the Allende government in Chile in 1971, and the Turkish occupation of northern Cyprus in 1974.

Further, with the fall of Vietnam came a significant increase in refugee numbers not seen since post WWII. In 1978, the first boatloads of refugees from Vietnam arrived in Darwin. These groups landed after such treacherous journeys that the government began recruiting refugees directly from camps in Thailand, Indonesia and Malaysia. This influx was closely followed by refugees fleeing the aftermath of the Khmer Rouge regime in Cambodia in 1979. By 1985, 70,000 refugees from Southeast Asia had settled in Australia.

In 1971, in response to the needs of this new immigrant population, the Immigration (Education) Act was passed, emphasising Australia's responsibility for newly arrived immigrants' language education (Lo Bianco, 1997). In 1978, the Report on PostArrival Programs and Services for Migrants was released and informed the language and immigration policies of the time (Galbally, 1978). Moving on from the dominant monolingual, mono-cultural perspective of the post-war period, a multicultural Australia was emphasised, for example as the Australian Prime Minister of the time stated, "Australia is at a critical stage in developing a cohesive, united, multicultural nation" (Fraser, 1978, p. 2728, cited in Ozolins, 1993, p. 1). Multiculturalism was "invoked as a way of signalling divergence from a notional monoculturalism $\ldots$ and here it overlaps significantly with post-colonial concepts and debates" (Gunew, n.d.). As a result, however, some argued that this existed as "a covert form of assimilation and even of white 
supremacism" (Gunew, 2013, p.6), a view supported by Australian historian Geoffrey Blainey who stressed, at the time, that multiculturalism placed an "emphasis on what is different" (Blainey, 1984:153).

Even so, while adult migrant learners' settlement and language learning needs continued to be catered for by AMEP, up until this point there was no government response to the needs of school-aged students coming from non-English speaking backgrounds. This did not occur until the establishment of the Child Migrant Education Program (CMEP) in 1971 (Australian Institute of Multicultural Affairs, 1980; Lo Bianco, 2002; Lowes, 2004; Ozolins \& Clyne, 2001). Like AMEP, it was supported through Commonwealth funding and with its implementation came recognition of ESL teachers as a separate group of school teachers (Australian Institute of Multicultural Affairs, 1980). Although even this was fraught, as the funding model meant that ESL teachers did not always have the same rights as those teachers funded by their state jurisdictions (e.g., in Western Australia throughout the 1980s until the 2000s, ESL teachers could not gain permanent employment positions).

Commencing in 1978 and continuing into the 1980s, teaching programs catering for ESL school children included two separately funded programs: the New Arrivals program (Flohm, 2009; Moore, 2005; Patty, 2013b) and the Multicultural Education Program. In this context, the earlier post-war dismissal of specific child ESL needs was addressed, but even here these focussed programs were targeted at addressing observed educational deficits, rather than celebrating difference and the linguistic advantages of multilingualism. In these programs eligible students included those born overseas in a non-English-speaking country, and those having at least one parent born in a non-English-speaking country. In most cases, but depending on the different procedures of the various systems and sectors, eligibility was determined by the school (Australian Institute of Multicultural Affairs, 1980). Funding for the Multicultural Education Program was, however, discontinued in 1986 - the rationale for this included perceived administrative weaknesses, teacher inadequacy, the (mis)interpretation of the program's aims, and the impact of teaching languages other than English (Cahill, 1986). At this time the responsibility for supporting students with language backgrounds other than English, apart from newly arrived migrants and refugees, shifted to schools. Funding was provided for general ESL support, however, the 
primary focus was the beginning stages of English language learning and the promotion of English literacy. For example, in the early 1980s CMEP materials included resources developed for school-aged students such as Learning English in Australia (LEA) which was structural in design. Further, harnessing the younger learners' mother tongue was not part of the normal teaching cycle.

In contrast, for adult learners the structural approach that was used by AMEP teachers (i.e., the situational method), did utilise learners' mother tongue to promote the target language learning (Ingram, 2003, p. 6). In addition, after this period and reflecting the status of TESOL and second language acquisition as burgeoning fields of research, ESL teaching approaches became more learner-centred, needs-based and proficiency-focused. For example, by the mid-1980s theme-based and communicative language teaching (CLT) approaches were being used by many teachers (Burns \& de Silva Joyce, 2007; Feez, 1999a; Ingram, 2003). Those adopting a thematic approach focused on activities and language exercises surrounding a particular topic and those adopting CLT focused on real-life language use.

In fact, by the mid-1980s the general pedagogic trend moved from developing linguistic competence to developing communicative competence (Ingram, 2003, p. 2). For example, as the CMEP matured, teachers became more eclectic and many supplemented or replaced the LEA series altogether with mainstream texts and resources. Others focussed on the development of primary school level literacy and numeracy skills using resources developed specifically for young ESL learners in 1981 (e.g., Selected Materials for Infants Learning English (SMILE), Commonwealth Department of Education, 1981). However, as a consequence, the boundary between mainstream and ESL learning began to blur.

Despite the strong theoretical underpinning and important practical applications of communicative approaches, it was not long before a number of limitations began to emerge, particularly for adult learners. Coming from conservative educational backgrounds, learners were confused about what was expected of them and about the role of the teacher (Burns \& de Silva Joyce, $2007,2008)$. In addition, some were concerned at the lack of feedback on their progress. As Burns and de Silva Joyce (2007, p. 9) point out, there was "uncertainty about syllabus planning and content" (p. 9). In response to these limitations, a "visible 
pedagogy" was demanded (Bernstein, 1990, p. 73; Feez, 1998, p. $25)$.

\section{Late 1980 s to $2000 s$}

By the late 1980s, several major conflicts beyond Australia further contributed to the need for ESL services for migrants. For example, the 1989 Tiananmen Square incident triggered fear in thousands of Chinese students in Australia who then sought asylum through the Humanitarian Program (Australian Government, 2013c). Between 1992 and 1995 the break-up of former Yugoslavia resulted in the intake of non-English speaking migrants from this region. As a direct result of the Pinochet regime in Chile, a large number of political migrants were also supported to resettle in Australia. Other refugees came as a result of the Eritrean-Ethiopian War (1998-2000), the civil war in Sri Lanka, and the 1990-1991 Gulf War.

In 1991, the National Policy on Languages was revised and renamed the Australian Language and Literacy Policy (Dawkins, 1992). The revision of this policy had a major impact on ESL teaching (Department of Employment, Education and Training, 1991; Lo Bianco, 1997). Before its implementation, the Department of Employment, Education and Training received 340 written submissions opposing the change (Clyne, 1991) and its drastically reduced funding. However, despite this "turmoil" (Moore, 1995, p. 7) the less comprehensive and less inclusive policy was accepted. It emphasised the teaching of English as a second or foreign language (Ingram, 2003) and included greater recognition of Aboriginal students who spoke a traditional language or a creole as their first language: a possible reaction to the Australian Aboriginal people who "have succeeded in disassociating their concerns from discourses of multiculturalism" (Gunew, n.d.). However, the then Minister for Education, John Dawkins claimed that "English language training, is by far and away the most important part of this policy document" (Dawkins, 1991, p. 1).

Since the approval of the 1991 policy, newly arrived adult migrants have been entitled to 510 hours in the AMEP to reach a functional level of English to meet their settlement and vocational needs; to facilitate their community participation; and to allow them to enter the workforce (Burns \& de Silva Joyce, 2007; Ingram, 2003; Lowes, 2004; Piller \& Takahashi, 2011). Humanitarian entrants are entitled to additional hours, specifically 100 hours for those who have suffered trauma and torture, and 400 hours for 
those who are between 16 and 24 years old and have had less than seven years of formal education (Burns \& de Silva Joyce, 2007; Piller \& Takahashi, 2011).

Also at the beginning of the 1990s, a national competencybased curriculum for the AMEP was developed to improve its accountability and consistency. This led to the accreditation of the Certificates in Spoken and Written English (CSWE) (Burns \& de Silva Joyce, 2007; Lewis, 1993; Piller \& Takahashi, 2011). This curriculum aimed to provide adult migrant learners with information about available services and the Australian way of life for settlement purposes (Ingram, 2003). As Kim et al. (2012) point out, $65 \%$ of the tasks in the CSWE are settlement-focused. However, in spite of these changes to curricula, in the 2000s the AMEP was criticised for failing to assist migrants to develop adequate spoken and written skills for the workplace (Burns \& de Silva Joyce, 2007). As a result, the Language, Literacy and Numeracy Program funded by government and employers, and specifically designed to develop workplace and vocational skills with practical study at workplaces, was implemented (Burns \& de Silva Joyce, 2007).

Further changes were made to the funding of AMEP. In 1998 public tenders were invited to deliver the programs (Burns \& Joyce, 2007). This led to skilled migrants and their dependents with a low proficiency level of English (below IELTS 4.5) being required to partly fund their English lessons as the new service providers could not offer quality instruction with the financial resources allocated for curriculum development, teaching materials and assessment development (Cummings, 1998; Ingram, 2003). Thus provision of the migrant English programs was transferred to Technical and Further Education (TAFE) institutions and other Recognised Training Organisations (RTOs). With this change, tuition consisted of a preliminary course and three subsequent Certificate Levels. All courses continue to be offered, including an online mode for distance learning. An additional program entitled Settlement Language Pathways to Employment and Training (SLPET) was developed to focus directly on the language and literary needs of the workplace.

During this period, changes were also made to the way ESL students in schools were supported. Specifically there was a shift towards 'mainstreaming'. Specialist programs to support students fell from favour and there was an even stronger move towards focusing on English literacy. This period also saw the dominance of the text- or genre-based approach (Burns \& de Silva Joyce, 2007; 
Feez, 1998, 1999a, 1999b; Lewis, 1999; Mickan, 2004), underpinned by Systemic Functional Linguistic theory (Halliday 1994; Halliday \& Hasan 1985). In fact, the genre-based approach was adapted for TESOL for both school and adult learning (Burns \& de Silva Joyce, 2007; Feez, 1998; Feez, 1999b; Lewis, 1999) with it being introduced into the AMEP after 1995 (Feez, 1999b).

Other major initiatives in the assessment and evaluation of ESL learning also occurred during this time. Stemming from the Australian Language Levels (ALL) Project, the ESL Bandscales were developed by teams of educators led by the late Penny McKay to assess learning in English as a Second Language (Dooley \& Moore, 2009). An alternative set of ESL scales was also implemented at this time, although the Bandscales were perhaps more widely accepted by teachers, perhaps in part because of the way they were developed with considerable input from practising ESL school teachers.

\section{2000s}

During the decade of 2000-2010 over 1.2 million migrants arrived in Australia and between 2010 and 2013 average arrivals per year were around 146,000. In 2013 it was reported that 45 per cent of all Australians were either born overseas or had at least one parent born overseas. Of those migrants arriving between 2012 and 2013, some $62 \%$ were from non-English speaking countries. Thus the need for ESL instruction has continued to be strong (Department of Immigration and Border Protection, n.d.). Despite this, in more recent years the focus has moved from providing ESL instruction per se to the politically driven priority of "building a stronger, fairer Australia" (Australian Government, 2011, p.1), and the fate of ESL, particularly in contemporary Australian schools, but also for adult migrants in some states, has become "frighteningly insecure" (Flohm, 2009, p. 8).

In the adult learning context, 510 hours of English language instruction remains available to eligible migrants and humanitarian entrants who must register with a provider within six months of arrival and complete their course within five years. However, within the school system significant changes occurred in the late 1990s that impacted further on the provision of ESL. In 1997, the federal funding of the general ESL programs for immigrant schoolchildren (i.e., once they moved into mainstream classes) came to an end after twenty-eight years (Moore, 2005). The funding of ESL programs was now limited to newly arrived migrants only (i.e., in 
their first 12 months post arrival) and the onus shifted to state governments for providing support beyond this time. Some state systems and sectors had already been shouldering much of this responsibility, but for others it required considerable change to ensure that ESL support was available for those students no longer in New Arrivals programs. For example, a further 12 months was available "to those students entering or re-entering schooling at any age who, ... have been unable to access ongoing continuous schooling" (Department of Education and Training Western Australia, 2010, p. 9). Loopholes in the system also occurred at this time: in particular the case of children whose parents had work or 457 Visas for temporary skilled work in Australia for up to four years. These children did not qualify for the educational support offered to the families of permanent visa holders or humanitarian refugees (i.e., the New Arrivals program - ESL-NA). As a result, further funding was made "to schools with significant numbers of ESL 457 students" (Education and Health Standing Committee, 2009, p. 20). More recently in Western Australia, all skilled migrants in this visa category have been required to pay a fee for their children to attend school - whether or not they require ESL support. What will happen in this regard in the current political context will no doubt unfold in the coming years, although with the recent changes to the 457 category there is little cause for optimism .

Currently, instead of directly funding ESL teaching, some state governments provide schools with financial resources which principals are at liberty to use to suit the needs of their ESL students. Despite the political actions and professional development provided through organisations such as the Australian Council of TESOL Associations (ACTA) (and its various state bodies), and in the face of considerable research by members of the Applied Linguistics Association of Australia, focus on the specific needs of ESL students remains at risk.

Accordingly, dedicated funding for ESL teachers is threatened and ESL job cuts have occurred despite the increase in ESL students in most schools (Patty, 2013a; Tucker, 2011; Lewis, 2012). The fact that there is no mandatory ESL allocation with the passing of the responsibility to the schools has been severely criticised (Flohm, 2009) leading to the further fear that migrant and refugee students might "easily slip through the cracks" (McNeilage, 2014, p. 13). Similar concerns have been addressed by the NSW ESL and Refugee Education Working Party with regard to the NSW's Local 
Schools, Local Decisions (LSLD) policy reform described as "the beginning of the dismantling of system-wide, targeted ESL program support infrastructure" (NSW ESL and Refugee Education Working Party, n.d.).

In practical terms, ESL school students are being merged into mainstream classrooms even when their English proficiency is not sufficient. In some states ESL students are now joining mainstream classes after only two terms of intensive English rather than three (Tucker, 2011). A further major concern is that many ESL school-aged children are taught by mainstream teachers using mainstream pedagogies, and by teachers who often do not have sufficient understanding of, or background in, the type of teaching practices required to support ESL learners. Methods used, for instance, may reinforce a deficit view of ESL students reflecting the post-colonial perspective of years gone by. Moreover, for many schools, responding to benchmarks imposed by the National Assessment Program - Literacy and Numeracy (NAPLAN) or the Programme for International Student Assessment (PISA) means most effort is put into these students "catching up" to the level of their mainstream peers, without due consideration of their actual needs and backgrounds - including the knowledge and experiences that they bring to learning.

With the notion of 'a fairer Australia' comes the concept of 'equality' and the temptation that 'one [pedagogical] size fits all' and so an eagerness to move ESL learners into mainstream prevails. However, with the more recent formal recognition of the second language or dialect status of some learners has meant that second language pedagogy may be regaining a foothold, albeit a small one. The uniqueness or 'otherness' of the ESL candidate is again acknowledged - be it more positively - with leaners now being described as EAL/D (English as an Additional Language or Dialect) learners emphasising the possibility that they already know one or more languages - an initiative echoed in Michell and Turnbull's (2016) whole-school approach to EAL policies, programs and practices. Methodologies that have emerged to support this cohort include Content-Based Instruction (CBI) and Content and Language Integrated Learning (CLIL) which are used with varying degrees of conscious planning and active pedagogy. Learners are extensively supported across the curriculum with resources specifically for Maths, Science and History as well as for English (for example, the ACARA English as an Additional Language or Dialect: Teacher Resource and the ACTA EAL/D Elaborations of the 
Australian Professional Standards for Teachers which have been endorsed by the Australian Institute for Teaching and School Leadership (AITSL). However, how well this translates into practice has not yet been evaluated in any large scale.

Further, despite the extensive literature that abounds regarding second language teaching methodology, including a move towards analytic syllabuses reflected in such things as TaskBased teaching which emerged from its predecessor Communicative Language Teaching, in practice ESL teaching has remained eclectic. Teachers tend to adopt various practices to address what they believe their students need. However, a frequent unfortunate interpretation of these needs at the school level is to succeed in the national testing regime (NAPLAN) meaning that EAL/D teaching has a strong mainstream literacy and numeracy focus at the cost of a foundational, contextual and language focus.

\section{Other ESL streams}

Although tangential to the focus of this paper, Australia's "ESL history" is not complete without some mention of the establishment of privately funded language schools and universities offering intensive English language courses. Since the mid-1980s, with English deemed an international language, Australia has become a place to learn English. An increased need for ESL instruction at university level was also recognised. Between 2003-2008 the number of English language students attending these programs doubled. Even after the Asian and then Global financial crises, international students have continued to enrol in these classes with 163,542 international students commencing English language programs in Australia in 2014 (English Australia, 2015), skyrocketing to 457,243 in 2017 (Department of Education and Training, 2017).

A further positive move concerns those students who are speakers of traditional Aboriginal languages, of creole languages, and/or Aboriginal English. The needs of these students are represented in programs addressing EAL/D (English as an Additional Language or Dialect) (see Welch, Konigsberg, Rochecouste \& Collard, 2015) as indicated above. Yet the development of Aboriginal students' proficiency in their various linguistic codes within classrooms continues to be an educational area fraught with difficulty due to a lack of awareness (Nguyen et al., 2014; Oliver, Rochecouste, Vanderford, \& Grote, 2011) or pedagogical approaches that can be uncomfortable and alienating for these students (Forrest, 2013; Nguyen et al., 2014). As a result, 
in many Australian classrooms, Aboriginal students experience difficulty moving between the distinct cultural and linguistic domains and are left struggling (Oliver et al, 2011). To this end, several recent resources have been developed to improve the educational outcomes of Aboriginal and Torres Strait Islander students. These include the Capability Framework: Teaching Aboriginal and Torres Strait Islander EAL/D leaners (The State of Queensland, Department of Education and Training, 2013), and the Aboriginal Cultural Standards Framework (Department of Education, Western Australia, 2015).

\section{Conclusion}

With the absence of firmly established professional recognition in the education context, the provision of ESL instruction has suffered the impact of numerous external forces despite the agitations of those associations aligned with this field. The situation described above shows a range of responses to a constantly shifting scene of policy, pedagogy and funding. Underlying this is the ever-present spectre of Post-colonialism and 'otherness'. In the post-WWII period the evolving political view of immigrants meant that ESL learners in Australia were required to assimilate from the 'other' to a so-called Anglo-Celtic norm by way of English instruction if an adult, or total immersion if a child. Next, 'otherness' was celebrated under the auspices of a policy of multiculturalism with the recognition of community languages and cultural diversity. Finally, the perspective of legislators has moved to creating "a fairer Australia" encompassing recognition of existing linguistic skills which includes Indigenous languages and the gaining of an additional linguistic repertoire - whether a language or a dialect. This demonstrates a somewhat more appreciative interpretation of 'otherness/difference'.

Over time the profile of learners has also changed from educating prospective Australian citizens to including temporary skilled employees and students. In response to these forces, funding for ESL has been $a d h o c$ and requiring continual adjustment to close loopholes. Moreover, this ever-changing scene has occurred in the face of structural changes in the education system with, for example, the introduction of the national curriculum and assessment processes which go against the trend of devolving funding responsibilities to the states and subsequently to individual schools. Such a situation has provided the profession of ESL teaching with little solid ground. 
To some extent, however, stability for the profession has been recently enhanced with the expansion of ESL to EAL/D. The range of resources that have accompanied this initiative (see ACARA, 2013; ACTA, 2015) has also meant that these learners are now recognised and can potentially be assisted in other areas of the curriculum. Whether or not this translates into a strengthened position for EAL/D teachers and learners is yet to be seen.

\section{References}

Australian Curriculum, Assessment and Reporting Authority (ACARA) (2013). English as an Additional Language or Dialect: Teacher Resource. Accessed 4.6.2016: http://www.acara.edu.au/ curriculum/student-diversity/english-as-an-additional-Languageor-dialect

Australian Council of TESOL Associations (ACTA) (2015). EAL/D Elaborations of the Australian Professional Standards for Teachers. Accessed 4.6.2016: http://tesol.org.au/RESOURCES/AustralianProfessional-Standards-for-Teachers

Australian Government (2011). Foundations for a stronger, fairer Australia.

Retrieved from https://www.rdasydney.org.au/imagesDB/ wysiwyg/SocialInclusionreport2011.pdf

Australian Government. (1975). Situational English part 3. Canberra: Australian Government. Publishing Service.

Australian Institute of Multicultural Affairs. (1980). Review of multicultural and migrant education. Melbourne: Australian Institute of Multicultural Affairs.

Bernstein, B. (1990). The structuring of pedagogical discourse (Vol. 4): Class, codes and control. London and Boston: Routledge and Kegan Paul.

Blainey, G. (1984). All For Australia, North Ryde, NSW: Methuen Haynes.

Burns, A. \& de Silva Joyce, H. (2007). Adult ESL programs in Australia. Prospect, 22(3), 5-17.

Burns, A., \& de Silva Joyce, H. (2008). Clearly teaching. Sydney: NCELTR.

Cahill, D. (1986). An evaluation of Australia's multicultural education program. Journal of Multilingual and Multicultural Development, 7(1), 55-69. DOI: 10.1080/01434632.1986.9994230.

Clyne, M. (1991). Australia's language policies: Are we going backwards? In A. Liddicoat (Ed.), Language planning and language 
policy in Australia. Australian Review of Applied Linguistics, 8, 3-22.

Collins, J. (1988). Migrant hands in a distant land: Australia's post-war immigration. Sydney: Pluto Press.

Commonwealth Department of Education. (1981). Smile selected materials for infants learning English: Beginning English under eight. Canberra: Australian Government Publishing Service.

Cummings, A. (1998). Skill service or industry: The organisation of settlement programs for adults learning English in Canada and Australia. Prospect, 13(3), 36-41.

Dawkins, J. (1991, Sep 2nd). Transcript of John Dawkins, Minister for Employment, Education and Training press conference re Australia's language - the Australian language and literacy policy. Canberra: Office of the Minister.

Dawkins, J. (1992). Australian Language and Literacy Policy. Canberra: Australian Government Publishing Service.

Department of Employment, Education and Training. (1991). Australia's language: the Australian language and literacy policy. Canberra: A.G.P.S.

Department of Education and Training (2017). International student data. Retrieved from https://internationaleducation.gov. $\mathrm{au} /$ research/International-Student-Data/Pages/default.aspx

Department of Education and Training Western Australia. (2010). ESL/ESD Progress Map English as a Second Language English as a Second Dialect. Perth: Department of Education and Training.

Department of Education, Western Australia. (2015). Aboriginal Cultural Standards Framework. Perth: Department of Education.

Dooley, K \& Moore H. (2009). Penny McKay 1948-2009: A leader in English language education. TESOL in Context, 19(2), 50-66.

Education and Health Standing Committee. (2009). Children Missing Out - Education Support For: - Students On 457 Visas - Students With A Disability. Report No. 4 In The 38th Parliament.

English Australia. (2015). Fact Sheet ELICOS Industry Statistics 2014. Available: https://www.englishaustralia.com.au/ visageimages/about_us/our_industry/understanding_our_ industry/02_FS_ELICOS_Industry_Statistics_2014.pdf

Faine, M. (2008). At Home in Australian: Identity, Nation and the Teaching of English as a Second Language to Adult Immigrants in Australia. PhD thesis, Faculty of Education, Monash University, Victoria, Australia. 
Feez, S. (1998). Text-based syllabus design. Sydney: National Centre for English Language Teaching and Research.

Feez, S. (1999a). Text-based syllabus design. Interchange, 34, $5-11$

Feez, S. (1999b). Text-based syllabus design. TESOL in Context, 9(1), 11-14.

Flohm, A. (2009, Feb 14th). ESL's future is not so certain. Education, p. 8.

Fraser, M. (1978, May 30th). CPD House of Representative, v.109, pp. 2728-2731.

Galbally, F. (1978). Review of Post-Arrival Programs and Services. Canberra: Australian Government Publishing Service.

Giroux, H. A. (1994). Living dangerously: Identity politics and the new cultural racism. In H. A. Giroux \& P. McLaren (Eds.), Between borders (pp. 29-55). London New York: Routledge.

Gunew, S. (n.d.) Postcolonialism and Multiculturalism: Between Race and Ethnicity. Accessed 18 April 2017: http://faculty.arts.ubc. ca/sgunew/RACE.HTM

Gunew, S. (2013) Haunted Nations: The Colonial Dimension of Multiculturalisms (Transformations). UK: Routledge.

Halliday, M. A. K. (1994). An introduction to functional grammar (2nd ed.). London: Edward Arnold.

Halliday, M.A.K. \& Hasan, R. (1985). Language, context and text: aspects of language in a social-semiotic perspective. Waurn Ponds, Vic: Deakin University.

Hannan, M. (2009). Righting wrongs and writing rights into language policy in Australia. Tamara Journal, 8(2), 245-257.

Ingram, D. E. (1989). Language-in-education planning. Annual Review of Applied Linguistics, 10, 53-78.

Ingram, D. E. (2003). English language policy in Australia. Paper presented at the 2003 Summer International Conference of the Korea Association of Teachers of English (KATE), Chungnam National University, Daejeon City, Korea, 26 to 28 June, 2003.

Kim, S. H. O., Ehrich, J. \& Ficorilli. L. (2012). Perceptions of settlement well-being, language proficiency, and employment: An investigation of immigrant adult language learners in Australia. International Journal of Intercultural Relations, 36, 41- 52.

Lewis, B. C. (2012, September 18th). Call for parents to lobby over funding cuts. Penrith City Star [no page number].

Lewis, C. (1999). Vygotsky and text-based approaches. Interchange, 34, 17-24. 
Lewis, R. (1993). Competency-based curricula and the Certificate in Spoken and Written English. TESOL in Context, 3(1), 12-13.

Lo Bianco, J. (1997). English and pluralistic policies: The case of Australia. In Eggington, W. \& Wren, H. (Eds.), Language policy:Dominant English pluralist challenges (pp. 107-119). Amsterdam; Philadelphia: J. Benjamins.

Lo Bianco, J. (2002). ESL in a time of literacy: A challenge for policy and for teaching. TESOL in Context, 12(1), 3-9.

Lo Bianco, J. (2008). Language policy and education in Australia. In S. May \& N. H. Hornberger (Eds.), Encyclopedia of Language and Education, Volume 1: Language Policy and Political Issues inEducation, (2nd ed.,pp.343-353). LLC:SpringerScience+Business Media LLC.

Lo Bianco, J. (2009). Language teaching and learning: Some hard decisions. Babel, 44(1), 36-38.

Lowes, D. (2004). Australian politics and the AMEP. TESOL in Context, 13(2), 16-20.

Martin, S, (1998). New Life, New Language: The History of the Adult Migrant English Program. Sydney: National Centre for English Language Teaching and Research.

McKay, P. (2001). National literacy benchmarks and the outstreaming of ESL learners. In J. Lo Bianco \& R. Wickert (Eds.), Australian policy activism in language and literacy (pp. 221-239). Melbourne: Language Australia Publications.

McNeilage, A. (2014, January 31st). Lack of language training prompts fears for migrant students: Education. Sydney Morning Herald, p. 13.

Mickan, P. (2004). Teaching strategies. In Conlan, C. (Ed.), Teaching English language in Australia: Theoretical perspectives and practical issues. Perth, W.A.: API Network, Australia Research Institute.

Michell, M. \& Turnbull, M. (2016). Leading the development of an effective whole-school English as an Additional Language (EAL) program. Presented at the 2016 ACTA International Conference, Perth 7-10 April.

Moore, H. (1995). Telling the history of the 1991 Australian Language and Literacy Policy. TESOL in Context, 5(1), 6-20.

Moore, H. (2005). Identifying "the target population": A genealogy of policy-making for English as a second language (ESL) in Australian schools (1947 - 1997). PhD thesis, University of Toronto, Canada. 
Ann Arbor: ProQuest, UMI Dissertations Publishing.

Moore, H. (2007). Non-language policies and ESL: Some connections. TESOL Quarterly, 41(3), 573-583.

NSW ESL and Refugee Education Working Party. (n.d.) Letter to The Right Hon. Adrian Piccolo, MP. Accessed 4.6.2016: https:// www.nswtf.org.au/files/university_correspondence_to_a_piccoli_ mp.pdf

Ozolins, U. (1993). The politics of language in Australia. Cambridge: Cambridge University Press.

Ozolins, U. \& Clyne, M. (2001). Immigration and language policy in Australia. In G. Extra \& D. Gorter (Eds.), The other languages of Europe (pp. 371-390). Artarmon, NSW: Multilingual Matters.

Patty, A. (2013a, May 28th). Academics to fight against O'Farrell's English language funding cuts: State Politics. Sydney Morning Herald, p. 6.

Patty, A. (2013b, November 25th). English aid scrapped in new funding arrangements: State Politics - Education - 31 positions to go. Sydney Morning Herald, p. 10.

Pavlenko, A. (2003). I never knew I was a bilingual: Reimagining teacher identities in TESOL. Journal of Language, Identity and Education, 2(4), 251-268.

Piller, I. \& Takahashi, K. (2011). Language, migration and human rights. In Wodak, R., Johnstone, B. \& Kerswill, P. (Eds.), The SAGE handbook of sociolinguistics (pp. 583-597). London: SAGE.

Said, E. (1989). Representing the Colonized: Anthropology's Interlocutors. Critical Inquiry 15, 205-25.

Said, E. (1995). Orientalism: Western conceptions of the Orient. Middlesex: Penguin Books.

Sakerllaridou, E. (1995). Interculturalism - Or the Rape of the Other: Some Problems of Representation in Contemporary British Theatre. Gramma, 3, 141-155.

State of Queensland (the), Department of Education \& Training. (2013). Capability Framework: Teaching Aboriginal and Torres Strait Islander EAL/D leaners. Brisbane: Department of Education \& Training.

Tucker, B. (2011, August 6th). Fears ACT rushing nonEnglish speakers. The Canberra Times, p. 7.

Welch, A., Königsberg, P., Rochecouste, J. \& Collard. G. (2015). Aboriginal Education in Australia: Policies, Problems, Prospects. In Crossley, M., Hancock, G., \& Sprague, T. (Eds.), 
Education in Australia, New Zealand and the Pacific (pp. 91-110). London: Bloomsbury.

Rhonda Oliver is a professor at Curtin University. She began her career as a school ESL teacher. Her research focuses on studies of second language acquisition, including large scale studies on international and Indigenous university students, and on migrant and Aboriginal children acquiring English as an additional language/Dialect.

Rhonda.oliver@curtin.edu.au

Judith Rochecouste has taught Linguistics and academic English at several universities and has conducted extensive research into indigenous and international university student experience. She currently develops online materials for instruction in academic English and for teaching English as an additional language/ dialect.

lingwa.consultancy@gmail.com

Bich Nguyen is a research associate at Curtin University. She has published research papers and book chapters in World Englishes, Functional Linguistics, SLA and Aboriginal education. Her research directions are to further investigate ways to improve educational outcomes for primary and secondary students who speak English as an additional language or dialect.

nhnbich@yahoo.com 